\title{
Impact of Higher Order Thinking Skills (HOTS) Module Based on the Cognitive Apprenticeship Model (CAM) on Student's Performance
}

\author{
Noorashikim Noor Ibrahim \\ Institute of Teacher Education, Kota Bharu Campus, Kelantan, Malaysia \\ https://orcid.org/0000-0002-2703-9840 \\ Ahmad Fauzi Mohd Ayub and Aida Suraya Md. Yunus \\ Universiti Putra Malaysia, Serdang, Malaysia \\ https:// orcid.org/0000-0002-4313-2922 \\ https://orcid.org/0000-0002-8742-4855
}

\begin{abstract}
This study intended to examine the difference in students' performances in terms of measurement and geometry between urban and rural schools. This research used a quasi-experimental design. This study involved a total of 63 students from urban school and 51 students from the rural school. This study conducted a pre-test, post-test, and post-delayed test to measure the students' performance. The treatment group utilized the Higher Order Thinking Skills (HOTS) based Module framed Cognitive Apprenticeship Model (CAM). The analysis of covariance showed that there is a significant difference between the post-test and post-delayed tests for the urban school. This finding revealed that the HOTS approach in teaching mathematics was more effective than the conventional teaching approach for students in an urban school. However, the result of rural schools showed that there is no significant difference in both tests. This result revealed that teachers and students from rural schools need more time to familiarize and practice the use of the HOTS approach. Hence, continuously using this approach in teaching and learning in the future should be recommended.
\end{abstract}

Keywords: Higher-order thinking skills; academic performance; measurement and geometry; experimental study; rural and urban area

\section{Introduction}

A few years ago, international studies of students, the International Student Assessment Program, and the Developments in International Mathematics and Science Research (TIMSS) seemed to compare the quality of education systems directly across different countries (Mullis, Martin, Kennedy \& Sainsbury, 2009). These programs assess a wide range of cognitive skills in mathematics and science. In primary schools, analytical performance refers to the outcome of the 
mathematics test. In 2015, Malaysian students had better results in TIMSS, with the highest increase of 25 points among 18 nations that have exhibited improvements in mathematics (Aziz, 2016). Despite Malaysia being now in midtable in the list of participating countries, it still aimed to get a score of 500 points in TIMSS 2019 (Bernama, 2016). Researchers conducted studies on analytical performance across the globe. The factors that influence the analytical performance among grade 8 Malaysian students were the lack of higher-order thinking skills (HOTS) (Nor' ain \& Mohan, 2015; Uwaezuoke \& Ekwueme, 2015) and unfamiliarity with open-ended questions (Ministry of Education Malaysia, 2014). Hence, educators must expend their effort to promote HOTS among students and achieve the government's desire for a world-class education. In Malaysia, explaining and practicing in mathematics dominated about $58 \%$ of the teaching and learning process; the rest goes for reviewing homework, re-teaching, taking tests, and participating in activities that are not related to the lesson content (Zabit, 2010). Mullis, Martin, and Foy (2008) claimed that Malaysian mathematics teachers gave more attention to the product of thinking and less emphasis on the outcomes of the learning.

Moreover, the traditional method of teaching mathematics still exists and will continue to occur in Malaysian classrooms (Zanzali, Abdullah, Ismail, Nordin \& Surif, 2011). Research showed that teacher-centered teaching using textbooks and an emphasis on procedural understanding in mathematics was related to student's achievement in mathematics (Zanzali et al., 2011). Thus, the raised concern calls for more effective techniques and alternative teaching and learning approaches in infusing HOTS in mathematics content.

\section{Literature Review}

The Malaysian education system has undergone a rapid change along with changes in lifestyle towards the $21^{\text {st }}$ century. Education in Malaysia has changed three times in terms of the curriculum, which are before 1982, namely the KLSR [Old Primary School Curriculum], then the KBSR [New Primary School Curriculum], and KSSR [Standard Based Curriculum for Primary Schools]. KSSR was designed and launched in 2011 to fulfill the needs of the students in facing the $21^{\text {st }}$ century. The focus in KSSR for the teaching and learning process is to help students understand the mathematics knowledge deeply so that they can apply the concepts, values, and means of mathematics in the actual world (Ministry of Education Malaysia, 2011). KSSR emphasis more on HOTS. Thus, teachers were accountable for creating opportunities that deal with HOTS. Since the HOTS approach is entirely new in the curriculum and education system, hence it is a great challenge to the teachers.

\subsection{Higher Order Thinking Skills (HOTS)}

HOTS is one of the essential skills in the $21^{\text {st }}$ century. In which the world acknowledged as accelerative skills in this changing era. Individuals not only need to have an education but also be able to think creatively and make the right decisions. (Huang, 2011). According to Richland and Simms (2015), it means that education in the $21^{\text {st }}$ century should highlight students' skills for HOTS, transfer, and flexible reasoning over memorizing facts. According to Bloom (1956), there 
are six skill groups in the cognitive domain. The first three levels in Bloom's taxonomy are knowledge, understanding, and application. This first level is considered a lower level of thinking skills (LOTS). Bloom thought the next three levels; analysis, synthesis and, evaluation as a higher level of thinking skills (HOTS) (Chang \& Mao, 1999; Pappas et al., 2012; Yahya et al., 2012). Later, these three levels were changed to analyze, evaluate, and create in Bloom's revised taxonomy.

\subsection{HOTS in Urban and Rural Schools}

According to a report released by TIMSS, school location has a significant impact on student achievement. Facilities such as libraries, media centers, and other facilities influence student learning (Mullis, Martin, Foy, and Arora, 2012). From the result of TIMSS 2015, students in urban schools achieved 470 points, whereas students in rural schools obtained 442 points in mathematics. Even though there is an increment of positions in both locations from TIMSS 2011, the scores are still considered moderate in achievement. The Department of Statistics Malaysia (2010) defines urban areas as gazetted areas, saturated districts bordering it, and a combination of the two. It has features such as; there is a population of at least 10,000 and less than 60 percent of the population aged 15 years and above are engaged in non-agricultural activities. The Department of Statistics Malaysia (2010) defines the rural areas as gazetted and non-gazetted regions with a population of fewer than 10,000 people. Rural schools experienced quality in school facilities such as internet and ICT infrastructures, lack of adequate instructional supplies (e.g., well-equipped libraries, laboratories and media center) and appropriate facilities for students (e.g., free textbooks) (Othman \& Muijs, 2013). However, urban schools have advantages in the facilities provided, educational resources, and appropriate infrastructures.

According to the Ministry of Education (2014), in the UPSR [Primary School Assessment Test], the gap between urban and rural students was almost $4 \%$ higher for urban schools. Researchers have conducted studies on the effect location towards mathematics learning around the world. Jayagandhi (2018) conducted a study to observe the continuous and comprehensive evaluation of HOTS in science among 150 students in Madurai district. The result revealed that students from urban schools performed better HOTS than rural students. Urban schools provided better knowledge and facilities that can increase the motivation of students towards learning. Wae, Mercuriani, and Paidi (2017) carried out a survey to describe the ability of HOTS students for biology in Ende district. The result showed that students from urban schools gained higher in the average score of knowledge compared to students from a rural school. It showed that with excellent infrastructure, availability of learning resources, transportation, good teaching quality, and a conducive learning environment could improve the knowledge of students in the urban school. Abdullah, Mokhtar, Halim, Ali, Tahir, and Kohar (2017) have conducted a study to determine the level of knowledge and practice of HOTS among mathematics teachers in the Terengganu district. The findings indicated that mathematics teachers who taught in rural schools gained higher expertise and used several strategies in applying HOTS. It happens because the environment in rural schools is more comfortable with smaller class 
sizes. Firdaus (2017) carried out a study to determine whether there is a difference in mathematical literacy among students who received problem-based learning and direct instruction in different areas of schools. The sample involved was fifthgrade students in Bandung.

The results showed that there is no significant difference between learning approaches and the location of the schools. However, there is an increase in the mathematical literacy of students who received problem-based learning and those students who received direct instruction in both urban and rural schools. Hence, the researcher recommended that the teacher should emphasize the teaching model with HOTS that had an impact on a student's mathematical literacy and HOTS. Hua and Ping (2017) conducted a study to evaluate the effectiveness of application information system-based in enhancing student's HOTS. They applied a mixed-methods approach in this research. The sample involved was only the standard five students and the teachers in Selangor. The result showed that there was a significant improvement in the use of information system-based in enhancing student's HOTS. Several factors that influenced the students were student's attitude, teacher's attraction, school facilities, and computer approach. Hence the use of information system-based in enhancing student's understanding of HOTS was suggested.

According to the TIMSS 2015 report, the average score for Malaysian students in the Measurement and Geometry is low compared to other content domains such as Number and Algebra. It showed that Malaysian students only have basic knowledge of Measurement and Geometry. Furthermore, analysis of the students' quality of answers in UPSR 2012, 2013 and 2014, (Ministry of Education, 2014) found that students were not proficient in the conversion of the unit, naming a three-dimensional shape, calculating area, and perimeter. They also failed to understand the problem-solving issues, transforming the information given in the questions to mathematics sentences (Malaysia Examination Syndicate, 2014). Hence, teachers must find ways to engage students in learning measurement and geometry and acquire HOTS. We can conclude that teachers need to diversify teaching methods to enhance HOTS among students in school.

\subsection{Cognitive Apprenticeship Model (CAM)}

Apprenticeship is a process through which a more experienced person assists a less experienced one by way of demonstration, support, and examples (Dennen \& Burner, 2008). It was a natural way to learn. Collins, Brown, and Newman (1989) proposed an alternative model of instruction called CAM that goes back to an apprenticeship but incorporates elements of schooling. CAM is a model of learning based on situated learning theory (Brown, Collin \& Dugnid, 1989; Renick, Levine \& Zeitz, 1991). CAM is a model of instruction that makes thinking visible to help students (Collins, Brown \& Holum, 1991; Collins, 2006; Dennen, 2008). Several studies suggested that by combining the learning strategies such as constructivism with CAM could increase students' understanding of the concept of the subject matter. (García-Cabrero, Hoover, Lajoie, Andrade-Santoyo, Quevedo-Rodríguez \& Wong, 2018; Putica \& Trivic, 2016; Saadati, Tarmizi \& Ayub, 2015; Kuo et al., 2012; ). Thus, this would support the students' HOTS. 


\subsection{Theoretical and Conceptual Framework}

In this study, the theoretical framework used was an adaptation from Dunkin and Biddle (1974), of classroom teaching study. The model distinguishes four variables as presage (teachers' experiences, characteristics, and beliefs about mathematics, teaching, and learning), context (students' experiences, school and community contexts, and classroom contexts), process (actual teaching and learning behaviors that take place inside the classroom) and product (immediate and lasting student effect). These variables are then connected to form the conceptual framework.

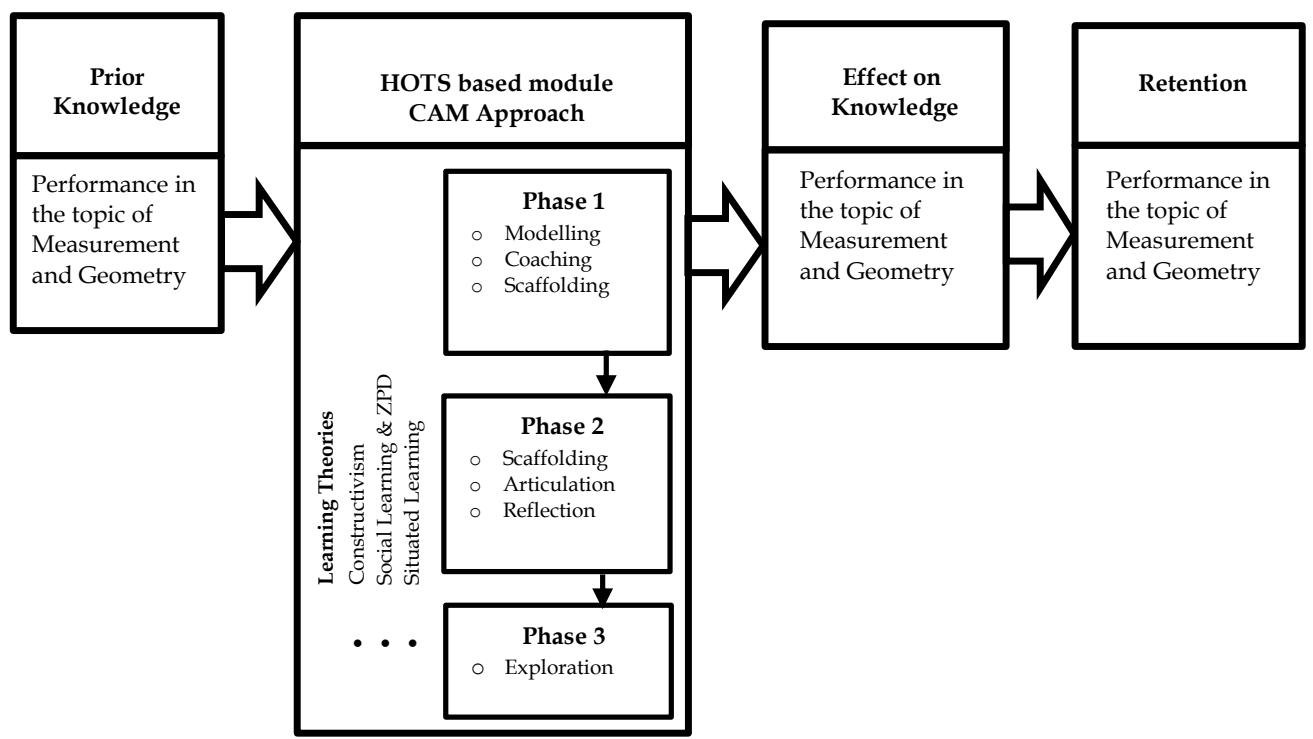

Figure 1: Conceptual Framework of the study

The conceptual framework is constructed based on the ADDIE model, and this model is used to develop a module, which has the characteristics of higher-order thinking skills. The researcher developed a module framed on the CAM that consists of three phases. The learning theories are embedded in the process of teaching and learning within these phases. The main ideas involved in the conceptual framework are Constructivism, Social Learning and ZPD, and Situated Learning.

\section{Objectives}

This study aims to investigate the difference in students' performances by using HOTS modules for the topics of measurement and geometry between urban and rural schools. Specifically, the study based on the next research objectives:

1. To determine the difference in the students' performance test scores (posttest) between the treatment and control groups while controlling the pre-test scores at the urban area in the topic of measurement and geometry.

2. To determine the difference in the students' performance test scores (posttest) between the treatment and control groups while controlling the pre-test scores in the rural area in the topic of measurement and geometry.

3. To determine the difference in the students' performance test scores (postdelayed test) between the treatment and control groups while controlling the pre-test scores at the urban area in the topic of measurement and geometry. 
4. To determine the difference in the students' performance test scores (postdelayed test) between the treatment and control groups while controlling the pre-test scores in the rural area in the topic of measurement and geometry.

The following research questions:

1. Is there a difference in the students' performance test scores (post-test) between the treatment and control groups while controlling the pre-test scores at the urban area in the topic of measurement and geometry?

2. Is there a difference in the students' performance test scores (post-test) between the treatment and control groups while controlling the pre-test scores in the rural area in the topic of measurement and geometry?

3. Is there a difference in the students' performance test scores (post-delayed test) between the treatment and control groups while controlling the pre-test scores at the urban area in the topic of measurement and geometry?

4. Is there a difference in the students' performance test scores (post-delayed test) between the treatment and control groups while controlling the pre-test scores in the rural area in the topic of measurement and geometry?

The research hypotheses are as follows.

$\mathrm{H}_{01} \quad$ There is no significant difference in the means of the students' performance test scores (post-test) between treatment and control groups while controlling pre-test scores in urban areas in the topic of Measurement and Geometry.

$\mathrm{H}_{02}$ There is no significant difference in the means of the students' performance test scores (post-test) between treatment and control groups while controlling pre-test scores in rural areas in the topic of Measurement and Geometry.

$\mathrm{H}_{03}$ There is no significant difference in the means of the students' performance test scores (post-delayed test) between treatment and control groups while controlling pre-test scores in urban areas in the topic of Measurement and Geometry.

$\mathrm{H}_{04}$ There is no significant difference in the means of the students' performance test scores (post-delayed test) between treatment and control groups while controlling pre-test scores in rural areas in the topic of Measurement and Geometry.

\section{Methodology}

Various experimental conditions happen in education, which requires the researcher to use intact groups. As it is the accessibility of the member, or as the environment prevents artificial group formation (Klassen, Creswell, Clark, Smith \& Meissner, 2012). This study utilized a quasi-experimental research design: the treatment group and the control group designated year five students. Assigning students randomly to both groups will disrupt classroom learning (Miller, Smith \& Pugatch, 2020). This study implemented a pretest-posttest control group design to evaluate the effectiveness of treatment to the respondents ( $\mathrm{Ni}$, Jong, Dison, Thomas, Yunus \& Suliman, 2020). Two national schools were selected, and this type of school was the most common in the district of Kota Bharu. This research used manual lottery. Each school was assigned a number - the researcher drawn two numbers. Two schools, each in urban and rural areas, were selected in this study. The 
researcher then numbered classes involved in each school chosen and drawn two numbers that represent classes from each school. Subsequently, the researcher numbered the selected classes to determine groups for treatment and control. Finally, the researcher drew two numbers to represent the experimental groups. A total of 69 students participated in an urban school, while a total of 63 students participated in a rural school.

\subsection{Instrumentation}

In this study, the researcher administered three tests (pre-test, post-test, and postdelayed test) to measure the students' performances during the treatment. The reliability of the tests was 0.78 for the pre-test, 0.79 for the post-test, and 0.71 for the post-delayed test. The test paper on the topics of measurement and geometry consisted of 12 subjective questions - the test questions based on higher-order thinking skills and short-answer items. A group of expert panels determined the reliability and validity of the existing. As for the module validity, the evaluation activity had gone through four types of assessment that involved expert review, development try-out, pilot-test, and field trial (Gagne, Wager, Golas, Keller \& Russell, 2005). In this study, three expert reviews validated the modules, two from the Institute of Teachers Education and one officer (School Improvement Specialist Coaches plus, SISC+) from the District Education Office. The panels gave a very constructive comment. The modules were updated based on the feedback given before conducting the pilot test. Based on the input, the instruction was improved. The actual study implemented the final version of the module.

\subsection{Research Procedures}

A pre-test was conducted on all groups to obtain the fundamental difference between the treatment and control groups. The purpose of the pre-test was to determine whether or not the means of both groups were significantly different and to provide baseline values regarding the variables measured. Therefore, the covariate in the analysis used the pre-test. The treatment group utilized the HOTSbased Module, whereas the control group utilized the conventional teaching approach. The post-test measured the students' performance after they used the HOTS-based Module in 12 weeks. The researcher then conducted a post-delayed test after the $14^{\text {th }}$ week of the intervention. The researcher used the term delayed effect to refer to the impact of treatment observed after some time. In the context of the study, the delayed effect meant remembering and utilizing what students have learned about HOTS during the treatment sessions. The teacher provided no additional treatment or feedback after the post-test and before the post-delayed test. In the instructional processes, different teachers handled the treatment and control groups. The school administrators have assigned teachers to a particular class since the beginning of school. Figure 2 presents the experimental procedure of this study. The teacher gave a short briefing to the students regarding the instructional intervention at the beginning of the course. After the researcher conducted the pre-tests on both groups, the teacher started adopting the HOTS approach for the treatment group and the conventional teaching approach for the control group. 


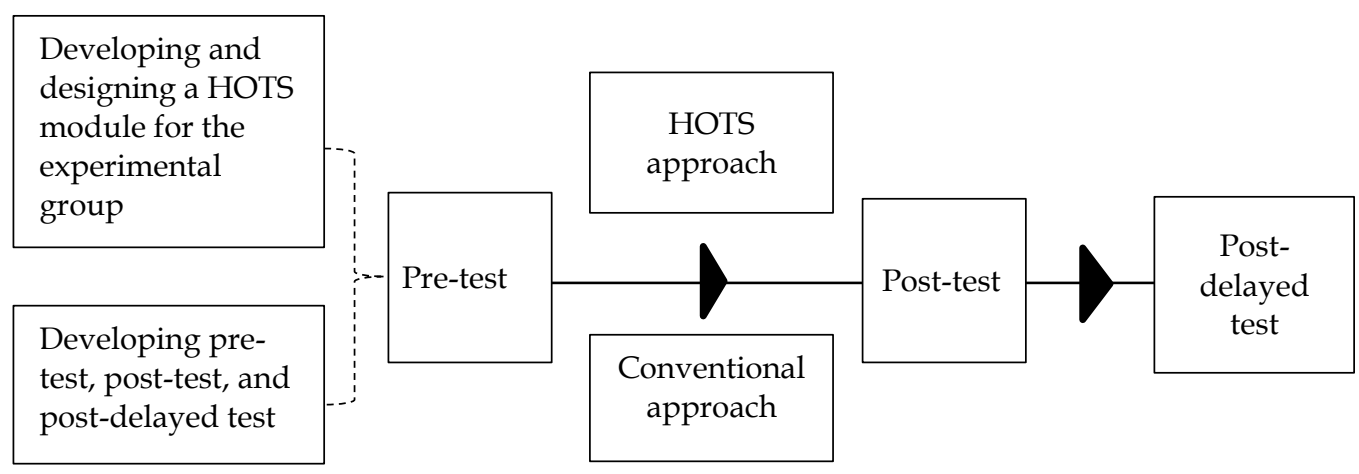

Figure 2: Representation of the research experiment

\section{Results and Analysis}

This section will discuss the findings referring to the research objectives of the study and the evaluation of the HOTS-based Module in the field trial.

Table 1 presents the mean and standard deviation of the performance test for both groups in an urban school. The performance score of the control group was higher in the post-test $(M=20.97, S D=4.882)$ compared with that of the treatment group $(M=12.87, S D=4.884)$. Whereas, the treatment group was higher in the postdelayed test $(M=15.32, S D=4.077)$ compared with that of the control group $(M=$ $14.19, S D=4.700)$.

Table 1: Descriptive statistics of post-test and post-delayed test scores in urban schools

\begin{tabular}{|l|l|l|l|l|}
\hline Tests & Group of students & Mean & Std. Deviation & N \\
\hline \multirow{2}{*}{ post-test } & Treatment & 12.87 & 4.884 & 31 \\
\cline { 2 - 5 } & Control & 20.97 & 4.882 & 32 \\
\hline \multirow{2}{*}{ post-delayed test } & Treatment & 15.32 & 4.077 & 31 \\
\cline { 2 - 5 } & Control & 14.19 & 4.700 & 32 \\
\hline
\end{tabular}

Table 2 presents the mean and standard deviation of the performance test for both groups in a rural school. The performance score of the control group was higher in the post-test $(M=13.26, S D=4.731)$ compared with that of the treatment group $(M=12.43, S D=2.775)$. Again, the control group was higher in the post-delayed test $(M=10.87, S D=5.354)$ compared with that of the treatment group $(M=10.14$, $S D=3.649)$.

Table 2: Descriptive statistics of Post-test and Post-delayed test scores in rural schools

\begin{tabular}{|l|l|l|l|l|}
\hline Tests & Group of students & Mean & Std. Deviation & $\mathbf{N}$ \\
\hline \multirow{2}{*}{ post-test } & Treatment & 12.43 & 2.755 & 28 \\
\cline { 2 - 5 } & Control & 13.26 & 4.731 & 23 \\
\hline \multirow{2}{*}{ post-delayed test } & Treatment & 10.14 & 3.649 & 28 \\
\cline { 2 - 5 } & Control & 10.87 & 5.354 & 23 \\
\hline
\end{tabular}

Levene's test was employed to examine the equality of variances in an urban school. The result revealed that Levene's test for post-test $[\mathrm{F}(1,61)=.454, \mathrm{p}=.503$ $>$.05] was not significant; hence, the assumption of homogeneity of variance was 
not violated. Whereas, the result of Levene's test for post-delayed test $[\mathrm{F}(1,61)=$ $1.767, \mathrm{p}=.189>.05]$ was not significant; hence, the assumption of homogeneity of variance was also not violated.

Table 3: Levene's Test of Equality of Error Variances of Post-test and post-delayed test Scores in urban schools

\begin{tabular}{|l|l|l|l|l|}
\hline Tests & F & df1 & df2 & Sig. \\
\hline post-test & .454 & 1 & 61 & .503 \\
\hline post-delayed test & 1.767 & 1 & 61 & .189 \\
\hline
\end{tabular}

Levene's test was employed to examine the equality of variances in the rural school. The result revealed that Levene's test for post-test $[\mathrm{F}(1,49)=2.813, \mathrm{p}=.100$ $>$.05] was not significant; hence, the assumption of homogeneity of variance was not violated. Whereas, the result of Levene's test for post-delayed test $[\mathrm{F}(1,49)=$ $.375, \mathrm{p}=.543>.05]$ was not significant; hence, the assumption of homogeneity of variance was also not violated.

Table 4: Levene's Test of Equality of Error Variances of Post-test and post-delayed test Scores in rural schools

\begin{tabular}{|l|l|l|l|l|}
\hline Tests & F & df1 & df2 & Sig. \\
\hline post-test & 2.813 & 1 & 49 & .100 \\
\hline post-delayed test & .375 & 1 & 49 & .543 \\
\hline
\end{tabular}

Table 5 shows that after adjusting the mean scores of the pre-tests, there was a significant difference in the mean post-test scores between the treatment and control groups $[\mathrm{F}(1,60)=26.733, \mathrm{p}=.000<.05]$. This study shows that students in the control group scored significantly better compared with those in the treatment group. Again, there was a significant difference between the two intervention groups in the post-delayed test scores in the performance test [F $(1,60)=4.877, \mathrm{p}=.031<.05]$. This result revealed that students in the treatment group indicated significantly better performance scores compared with those in the control group.

Table 5: Tests of Between-Subject Effects of Post-test and post-delayed test Scores in Urban Schools

\begin{tabular}{|l|l|l|l|l|l|l|l|}
\hline Tests & Source & $\begin{array}{l}\text { Type III } \\
\text { Sum of } \\
\text { Squares }\end{array}$ & df & $\begin{array}{l}\text { Mean } \\
\text { Squares }\end{array}$ & F & Sig. & $\begin{array}{l}\text { Partial Eta } \\
\text { Squared }\end{array}$ \\
\hline post-test & GROUP & 533.414 & 1 & 533.414 & 26.733 & .000 & .308 \\
\hline post-delayed test & GROUP & 83.390 & 1 & 83.390 & 4.877 & .031 & .075 \\
\hline
\end{tabular}

Table 6 shows that after adjusting the mean scores of the pre-tests for a rural school, there was no significant difference in the mean post-test scores between the treatment and control groups $[\mathrm{F}(1,48)=3.248, \mathrm{p}=.078>.05]$. Thus, $\mathrm{H}_{02}$ was accepted. The result implied that students in both groups did not differ in the post-test. Again, there was no significant difference between the two intervention groups in the post-delayed test scores in the performance test $[F(1,48)=2.360$, $p$ $=.129>.05]$. This result revealed that students exposed to both approaches did not differ in their post-delayed test. 
Table 6: Tests of Between-Subject Effects of Post-test and Post-delayed test Scores in Rural Schools

\begin{tabular}{|l|l|c|l|l|l|l|l|}
\hline Tests & Source & $\begin{array}{l}\text { Type III } \\
\text { Sum of } \\
\text { Squares }\end{array}$ & df & $\begin{array}{l}\text { Mean } \\
\text { Squares }\end{array}$ & F & Sig. & $\begin{array}{l}\text { Partial } \\
\text { Eta } \\
\text { Squared }\end{array}$ \\
\hline post-test & GROUP & 31.634 & 1 & 31.634 & 3.248 & .078 & .063 \\
\hline post-delayed test & GROUP & 42.285 & 1 & 42.285 & 2.360 & .129 & .031 \\
\hline
\end{tabular}

To evaluate the HOTS-based Module, the researcher produced objective-by-items graphs base on the pre-test and post-test items. Figures 4 and 5 illustrated the result of the students who used HOTS-based Module during the intervention. Figures 3 and 4, the graph suggested that there is an increment in performance score between pre-test and post-test among urban students, as well as students in the rural school. Figure 3 indicated that the performance of students in urban school achieved seven goals out of twelve goals in the pre-test. After the intervention, the students manage to achieve ten goals out of twelve goals in the post-test. Students have not yet reached two goals after the treatment period. Figure 4 indicated that the performance of students in rural schools made four goals out of twelve goals in the pre-test. After the intervention, the students can make six goals out of twelve goals in the post-test. There were six goals not yet achieved after the treatment period.

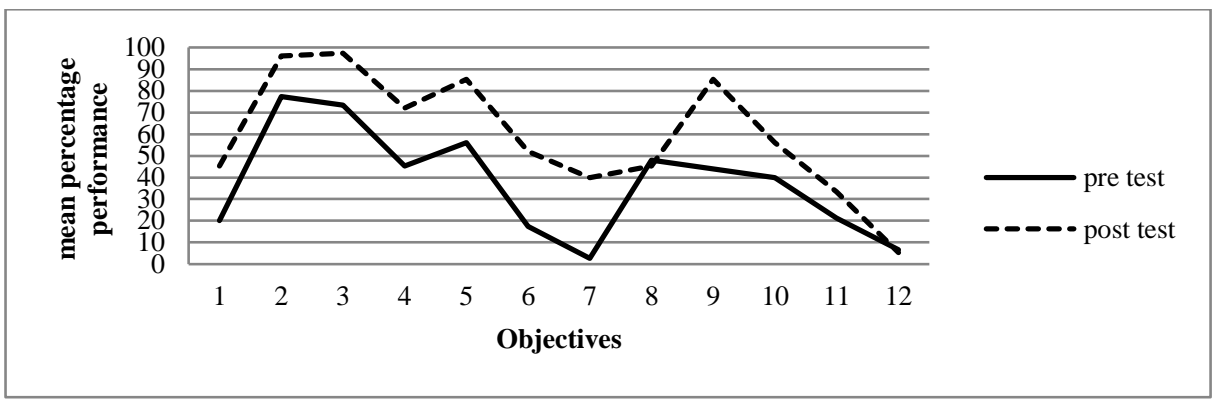

Figure 3: Pre-test and Post-test Showing Student's performance in Urban School for Field Trial

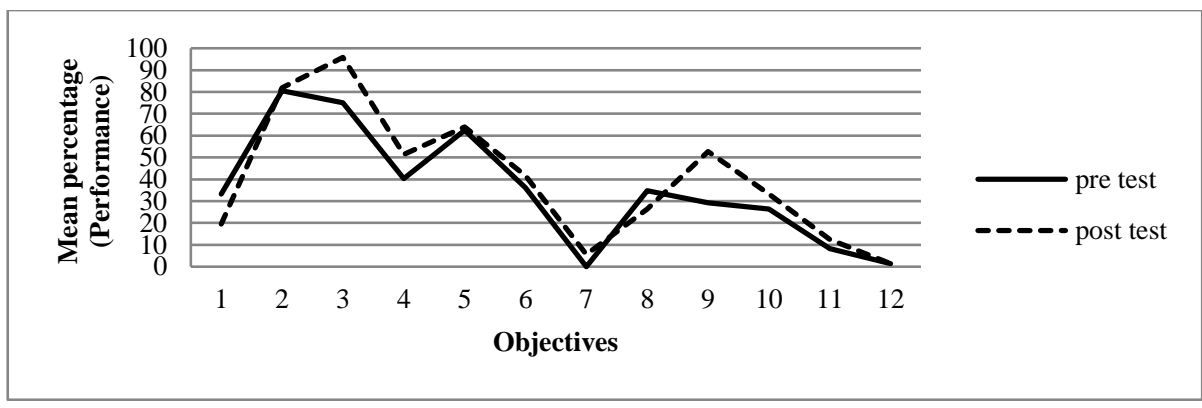

Figure 4: Pre-test and Post-test Showing Student's performance in Rural School for Field Trial

\section{Discussion}

Kuhs and Ball (1986) stated that teachers need to emphasize student achievement when teaching mathematics. Hence, one of the objectives of utilizing the HOTS approach was to improve learning performance. This study compared the use of the HOTS approach and the use of the conventional teaching approach between 
urban and rural schools. The result of the post-test revealed that students in the control group in urban school had significantly better performance scores compared with those in the treatment group. Whereas, the result showed that students in the treatment group in urban school had substantially better performance scores compared with those in the control group in the post-delayed test. The findings indicated that students' learning could facilitate within embedded activities in social contexts by exploring and applying CAM through HOTS-based Module (Averill, Drake \& Harvey, 2013; Brown, Collins \& Duguid, 1989). Assisting students by coaching and modeling in the way that expert planned, revised, and evaluated measurement and geometry problems and solutions were useful for students in the treatment group. Phase I included some activities based on coaching-modeling-scaffolding; however, this study did not report the exact changes. This result was also in line with Hendriks (2001) and Stockhausen and Zimitat (2002) that claimed CAM accommodated elementary schools' students' cognitive skills and reasoning capability. These skills are essential in promoting HOTS.

In contrast, the result of the post-test and the post-delayed test of the students from rural schools showed that there was no significant difference in the mean scores of the measurement and geometry performance. The result of the finding was in agreement with the study, both national and international (Ibrahim, Ayub, Yunus, Mahmud \& Bakar, 2019; Uwaezuoke \& Ekwueme, 2015; Nepal, 2017). However, this result was not consistent with the results of previous studies (Owi, Azhar, Mazlini \& Ang, 2017; Yee, Md Yunos, Othman, Hassan, Tee \& Mohamad, 2015; Saido et al., 2015) that indicated differences in performance score after using HOTS module. Two interpretations could explain this inconsistent result; the first interpretation is that the teaching approach using HOTS based Module is still new in Malaysia, especially for those students in a rural area. The conventional teaching approach is familiar and comfortable to conduct or follow for both teachers and students (Ayub, Mokhtar, Luan \& Tarmizi, 2010). According to Hagerty, Smith \& Goodwin, (2010), there are difficulties in converting from traditional teaching to the new teaching approach. The second interpretation is that more time needs to be given to teachers and students in rural area schools to be familiar and practice using HOTS. Teaching and learning using HOTS based Module that stressed on student-centered method tend to feel uncomfortable when being tried first.

Students in rural schools are not only unfamiliar with new contexts, but they have difficulty adapting new understandings to prior knowledge. Students also faced mathematical problems in the form of sentences (Vurayai, 2020). Time can overcome the problem, and this approach needs lots of commitments from the teacher (Hodge \& Kemp, 2006). Thus, a non-significance difference in mathematics performance for both groups of students might be explained by the limited time in adapting the HOTS approach.

This finding might also cause by several factors, such as family, excellent facilities and resources, and qualified teachers. The majority of the parents in urban areas are more educated than those in rural areas. The family upbringing was an essential factor in determining the students' academic performance (Aziz, 2016). 
The expectations of an educated family from their children's education are very high. Some experts believed that family expectations were the most influential factors of the students' decisions to pursue their learning (Davis-Kean, 2005; Benner, Boyle \& Sadler, 2016). A well-educated family with high income could manage to send their children to tuition classes to exhibit better achievement. Urban students could also afford to buy other books for their references. Hence, students in urban areas have access to more resources to improve their performance at school. Also, teachers play an essential role in enabling students to exhibit excellent performance. School administers assigned the most experienced and qualified teachers to urban schools, whereas new and lessexperienced teachers to rural schools.

According to Owolabi (1990), highly educated teachers prefer to serve in urban schools rather than in rural schools. The teacher in the treatment group in urban school felt that the HOTS approach could improve her knowledge and experience in developing her students' performance. She, therefore, continues to implement it even after the intervention. Previous studies stated that urban teachers had done a lot of coaching in preparing their students for examinations, thus encouraging the spirit of competition and rivalry. However, this may be lacking in rural students (Obe, 1984; Kemjika, 1989). The experienced and qualified teachers were capable of handling tasks provided in HOTS-based Module, which were increased by complexity and diversity, hence require students to use their conceptual knowledge to solve HOTS problems. Experienced and competent teachers will indirectly increase students' confidence in their learning (Nguyen \& Pham, 2018).

The use of HOTS-based Module framed CAM, which highly stressed on constructivism, could increase students' HOTS (Matanluk, Mohammad, Kiflee \& Imbug, 2013). They claimed that; through the choosy experience, students construct their knowledge to create a conceptual understanding which forms the basis of their learning. According to DeWolf, Bassok, and Holyoak (2015), it is significant to foster a sense of mathematics beyond teaching algorithmic procedures. Students with a high level of conceptual understanding were capable of solving problems in various forms and different settings (Che Ghazali \& Zakaria, 2011). This study showed that students in urban schools do better than those in a rural school in terms of location. Besides, a report by Ibrahim (2019) showed that students in the urban school had made fewer errors compared to those in the rural school. Students in urban schools have a very significant advantage whereby the environment helps them to enriches their academic knowledge, especially HOTS. The best opportunities, such as access to many resources equipped with urban students, which are not accessible to rural students. In other words, learning in an urban environment is advantageous to urban students, and it enriches their academic knowledge and HOTS.

\section{Limitation and Recommendation}

The researcher considered every attempt to remove errors in the aspects of design and analysis, hence considered a few limitations in this study. This study focuses on the effect of HOTS-based module learning instruction to promote HOTS by 
using the problem of measurement and geometry as an exemplar. In the topic of measurement, the researcher only covered four subtopics (length, mass and volume, shape and space, and angle. Investigating HOTS using other issues will have a different result. The study is limited to Year five students in a primary school in Kelantan. In this case, perhaps different results will be expected with students from other years and locations, varied in subject streams and backgrounds. Finally, the duration of this study is limited to a period of 12 weeks. A longer-term of instruction may provide a different result. The results showed that the HOTS-based module framed CAM has effectively help primary school students in both locations to enhance higher-order thinking skills in Measurement and Geometry. However, due to the time constraint and complexity, the HOTSbased Module frame CAM had covered only four subtopics of Measurement and Geometry. Thus, the researcher recommended the use of the same framework bounded in this study, the scope and treatment of the HOTS-based Module framed CAM could be drawn-out to include:

a. different subtopic and topics in both primary and secondary Mathematics

b. performances, problem-solving skills, conceptual and procedural knowledge by gender, and other capabilities.

c. learners with different mathematical abilities and learning style

d. different in research methodology

\section{Conclusion}

In conclusion, this study shows that despite the changes in mathematics education in schools today, there are still many students who cannot understand different parts of mathematics skillfully. Thus, it is rational for mathematics teachers to make a significant improvement in their teaching approaches. Therefore, the implementation of the HOTS approach should start at the primary school level. Teachers need to prudently approach the transformation at an early age so that students would have both the ability and support required to be competent in mathematics. Teachers and students also need to have positive beliefs in learning this new approach to improve their performance. Students with strong positive feelings will have an increased ability to learn mathematics and enhance their analytical performance (Bakar, 2019). The researcher recommended rural teachers are to diversify their teaching strategies and methods. Teachers would create a more efficient plan in teaching and learning using the HOTS approach. The HOTS

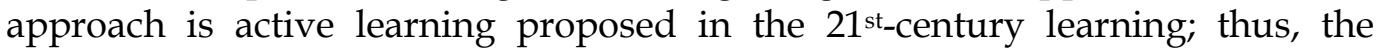
students who used the HOTS approach was able to grasp more strategies in problem-solving skills, concepts, and information in improving their decisionmaking skills.

\section{References}

Abdullah, A. H., Mokhtar, M., Halim, N. D. A., Ali, D. F., Tahir, L. M., \& Kohar, U. H. A. (2017). Mathematics Teachers' Level of Knowledge and Practice on the Implementation of Higher-Order Thinking Skills (HOTS). Eurasia Journal of Mathematics, Science $\mathcal{E} \quad$ Technology Education, 13(1). https://doi.org/10.12973/eurasia.2017.00601a

Ayub, A. F. M., Mokhtar, M. Z., Luan, W. S., \& Tarmizi, R. A. (2010). A comparison of two different technologies tools in tutoring Calculus. Procedia-Social and Behavioral Sciences, 2(2), 481-486. https://doi.org/10.1016/j.sbspro.2010.03.048 
Averill, R., Drake, M., \& Harvey, R. (2013). Coaching Pre-Service Teachers for Teaching Mathematics: The Views of Students. Mathematics Education Research Group of Australasia.

Aziz, H. (2016, Dec 7). Achieving better maths and science results. New Strait Times. Retrieved from http://www.nst.com.my/news/2016/12/195057/achievingbetter-maths-and-science-results

Bakar, S, A, Ayub, A. F. M, Gopal, K., \& Salim, N.R. (2019) The Influence of Students' Beliefs on Mathematical Problem Solving towards Mathematics Achievement among Malaysian Matriculation Students. Universal Journal of Educational Research. 7(10), 2243-2247. https://doi.org/10.13189/ujer.2019.071025

Bernama. (2016, Nov 30). TIMSS study: Science, Maths scores improve significantly. Retrieved from http://www.freemalaysiatoday.com/category/nation/2016/11/30/timss-studyscience-maths-scores-improve-significantly/

Benner, A. D., Boyle, A. E., \& Sadler, S. (2016). Parental involvement and adolescents' educational success: The roles of prior achievement and socioeconomic status. Journal of Youth and Adolescence, 45(6), 1053-1064. https://doi.org/10.1007/s10964-016-0431-4

Bloom, B. S. (Ed.). (1956). Taxonomy of educational objectives, Handbook I: The cognitive domain. New York, NY: McKay. https:// doi.org/10.4135/9781412958806.n446

Brown, J. S., Collins, A., \& Duguid, P. (1989). Situated cognition and the culture of learning. Educational researcher, 18(1), 32-42. https://doi.org/10.21236/ada204690

Chang, C. Y., \& Mao, S. L. (1999). The effects on students' cognitive achievement when using the cooperative learning method in earth science classrooms. School Science and Mathematics, 99(7), 374-379. https:// doi.org/10.1111/j.1949-8594.1999.tb17497.x

Che Ghazali, N. H., \& Zakaria, E. (2011). Students' procedural and conceptual understanding of mathematics. Australian Journal of Basic and Applied Sciences, 5(7), 684-691.

Collins, A. (2006). Cognitive apprenticeship. In K. R. Sawyer (Ed.). The Cambridge handbook of learning sciences (pp. 47-60). New York, NY: Cambridge University Press.

Collins, A., Brown, J. S., \& Holum, A. (1991). Cognitive apprenticeship: Making thinking visible. American educator, 15(3), 6-11. https://doi.org/10.5860/choice.28-0612

Collins, A., Brown, J. S., \& Newman, S. E. (1989). Cognitive apprenticeship: teaching the craft of reading, writing, and mathematics. In L. B. Resnick (Ed.), Knowing, learning, and instruction: essays in honor of Robert Glaser (pp. 453-494). Hillsdale, NJ: Erlbaum. https://doi.org/10.4324/9781315044408-2

Davis-Kean, P. E. (2005). The influence of parent education and family income on child achievement: the indirect role of parental expectations and the home environment. Journal of Family Psychology, 19(2), 294-304. https://doi.org/10.1037/0893-3200.19.2.294

Dennen, V. P., \& Burner, K. J. (2008). The cognitive apprenticeship model in educational practice. In Jonassen D., Spector M. J., Driscoll M., Merrill M. D., Merrienboer J. (Ed.), Handbook of research on educational communications and technology, (pp. 425-439). New York: Lawrence Erlbaum Associates, Taylor \& Francis Group.

DeWolf, M., Bassok, M., \& Holyoak, K. J. (2015). Conceptual structure and the procedural affordances of rational numbers: Relational reasoning with fractions and decimals. Journal of Experimental Psychology: General, 144(1), 127-150. Retrieve from http://dx.doi.org/10.1037/xge0000034

Dunkin, M. J., \& Biddle, B. J. (1974). The study of teaching. New York, NY: Holt, Rinehart \& Winston.

Firdaus, F. M. (2017). Improving Primary Students' Mathematical Literacy through Problem Based Learning and Direct Instruction. Educational Research and Reviews, 12(4), 212-219. https://doi.org/10.5897/err2016.3072 
Gagne, R. M., Wager, W. W., Golas, K. C., Keller, J. M., \& Russell, J. D. (2005). Principles of instructional design. Performance Improvement, 44(2), 44-46. https://doi.org/10.1002/pfi.4140440211

García-Cabrero, B., Hoover, M. L., Lajoie, S. P., Andrade-Santoyo, N. L., QuevedoRodríguez, L. M., \& Wong, J. (2018). Design of a learning-centered online environment: a cognitive apprenticeship approach. Educational Technology Research and Development, 66(3), 813-835. https://doi.org/10.1007/s11423-018-9582-1

Hagerty, G., Smith, S., \& Goodwin, D. (2010). Redesigning college algebra: Combining educational theory and web-based learning to improve student attitudes and performance. Primus, 20(5), 418-437. https:/ / doi.org/10.1080/10511970802354527

Hendricks, C. C. (2001). Teaching causal reasoning through cognitive apprenticeship: What are results from situated learning? The Journal of Educational Research, 94(5), 302-311. https:// doi.org/10.1080/00220670109598766

Hodge, J. K. (2006). The top ten things I have learned about discovery-based teaching. Problems, Resources, and Issues in Mathematics Undergraduate Studies, 16(2):154-161. https:/ / doi.org/10.1080/10511970608984143

Hua, A. K., \& Ping, O. W. (2017, May). Applied information system-based in enhancing students' understanding of higher-order thinking (HOTS). In AIP Conference Proceedings (pp. 030008). AIP Publishing. https://doi.org/10.1063/1.4983885

Huang, J. (2011). Applying higher-order thinking in E-learning design. Proceedings from ICHL '11: Fourth International Conference on Hybrid Learning, (pp. 135-145). Berlin, Heidelberg. Springer. https://doi.org/10.1007/978-3-642-22763-9_13

Ibrahim, N. N. Ayub, A. F. M. Yunus, A. S. M. Mahmud, R. Bakar, K. A. (2019). Effects of higher-order thinking module approach on students' performance at rural primary school. Malaysian Journal of Mathematical Sciences, 13(2), 211-229.

Ibrahim, N. N., Mohd Ayub, A. F., Md. Yunus, A. S., Gopal, K., \& Salim, N. R. (2019). Effects of HOTS-based Module Approach on Student's Errors in the Topic of Measurement and Geometry in Urban and Rural Schools. Universal Journal of Educational Research. 7(11), 2519-2535. https://doi.org/10.13189/ujer.2019.071132

Jayagandhi, M. (2018). A continuous and comprehensive evaluation of higher-order thinking skills (hots) in science among vii standard students. Paripex Indian Journal of Research, 7(10), 42-45.

Kemjika. O. G. (1989). Urban and rural differences in creative talents among primary school students in Lagos state. Lagos Education Review, 5(1).

Klassen, A. C., Creswell, J., Clark, V. L. P., Smith, K. C., \& Meissner, H. I. (2012). Best practices in mixed methods for quality of life research. Quality of Life Research, 21(3), 377-380. https:/ / doi.org/10.1007/s11136-012-0122-x

Kuhs, T. M., \& Ball, D. L. (1986). Approaches to teaching mathematics: Mapping the domains of knowledge, skills, and dispositions. East Lansing: Michigan State University, Center on Teacher Education.

Kuo, F. R., Hwang, G. J., Chen, S. C., \& Chen, S. Y. (2012). A cognitive apprenticeship approach to facilitating web-based collaborative problem-solving. Journal of Educational Technology \& Society, 15(4), 319-331.

Malaysian Examinations Syndicate. (2014). Lembaga Peperiksaan Malaysia Panduan Pengurusan PBS (Pentaksiran Berasaskan Sekolah) [Management of school-based assessment guidelines]. Retrieved July 17, 2014, from http:/ /apps2.moe.gov.my/lponline/v1/files/penerbitan/2014/Panduan_Pengur usan_PBS_21_April_2014 2.pdf

Matanluk, O., Mohammad, B., Kiflee, D. N. A., \& Imbug, M. (2013). The Effectiveness of Using Teaching Module based on Radical Constructivism toward Students Learning Process. Procedia-Social and Behavioural Sciences, 90(2013), 607-615. https://doi.org/10.1016/j.sbspro.2013.07.132 
Miller, C. J., Smith, S. N., \& Pugatch, M. (2020). Experimental and quasi-experimental designs in implementation research. Psychiatry Research, 283, 112452. https://doi.org/10.1016/j.psychres.2019.06.027

Ministry of Education in Malaysia. (2014). Dokumen Standard Kurikulum dan Pentaksiran KSSR Matematik Tahun 5. Kuala Lumpur: Curriculum Development Centre.

Ministry of Education in Malaysia. (2011). Kurikulum Standard Sekolah Rendah (KSSR). Kuala Lumpur: Curriculum Development Centre.

Mokhtar, M. Z., Tarmizi, R. A., Ayub, A. F. M. and Tarmizi, M. A. A. (2010). Enhancing calculus learning engineering students through problem-based learning. WSEAS transactions on Advances in Engineering Education, 7(8), 255 - 264.

Mullis, I. V., Martin, M. O., \& Foy, P. (2008). TIMSS 2007. International Mathematics Report. Findings from IEA's Trends in International Mathematics and Science Study at the Eight and Fourth Grades. Chestnut Hill, MA: Boston College.

Mullis, I. V. S., Martin, M. O., Kennedy, A. M., Trong, K. L. \& Sainsbury, M. (2009). PIRLS 2011 assessment framework. Chestnut Hill, MA: Lynch School of Education, Boston College.

Mullis, I. V., Martin, M. O., Foy, P., \& Arora, A. (2012). TIMSS 2011 international results in mathematics. International Association for the Evaluation of Educational Achievement. Herengracht, Amsterdam: The Netherlands.

National Research Council. (2007). National science education standards. Washington, DC: National Academies Press.

Nepal, B. (2017). Impact of Gender and Location on Mathematical Thinking and Mathematics Achievement. Journal of Advanced Academic Research, 3(3), 11-21.

Nguyen, G. N., \& Pham, H. T. (2018). Competency-Oriented Teaching of Primary School Math Problems in Vietnam. International Journal of Learning, Teaching, and Educational Research, 17(11). https://doi.org/10.26803/ijlter.17.11.3

Nor' ain, M., \& Mohan, C. (2015). Role of higher-order thinking skills in enhancing TIMSS Tasks. In Proceeding of International Conference on Research, Implementation, And Education of Mathematics and Sciences 2015 (ICRIEMS 2015), Yogyakarta State University. Faculty of Mathematics and Sciences at Yogyakarta State University.

Ni, C. K., Jong, B., Dison, M. A., Thomas, S. A., Yunus, M. M., \& Suliman, A. (2020). Enhancing Malaysian Primary Students' Vocabulary Skills using Pocable Game and Pear Deck. International Journal of Learning, Teaching, and Educational Research, 19(6). https://doi.org/10.26803/ijlter.19.6.9

Obe, E. O. (2004). Urban-rural and sex differences in the scholastic aptitude of primary school finalists in Lagos State. Education and Development, 4 (1 \& 2),39-45

Othman, M., \& Muijs, D. (2013). Educational quality differences in a middle-income country: the urban-rural gap in Malaysian primary schools. School Effectiveness and School Improvement, 24(1), 1-18. https://doi.org/10.1080/09243453.2012.691425

Owi, W. P., Ahmad, A., Adnan, M., and Hua, A. K. (2017). Effectiveness of higher-order thinking skills (hots) based i-think map concept towards primary students. In AIP Conference Proceedings, volume 1847, page 030009. https://doi.org/10.1063/1.4983886

Owolabi, J. (1990). An Introduction to School Mapping. Ibadan: University of Ibadan.

Pappas, E., Pierrakos, O., \& Nagel, R. (2013). Using Bloom's Taxonomy to teach sustainability in multiple contexts. Journal of Cleaner Production, 48, 54-64. https://doi.org/10.1016/j.jclepro.2012.09.039

Putica, K., \& Trivic, D. D. (2016). Cognitive apprenticeship as a vehicle for enhancing the understanding and functionalization of organic chemistry knowledge. Chemistry Education Research and Practice, 17(1), 172-196. https:// doi.org/10.1039/c5rp00179j

Renick, L. B., Levine, J. M., \& Zeitz, C. M. (Eds.). (1991). Perspectives on socially shared cognition. Washington, DC: American Psychological Association. 
Richland, L. E., \& Simms, N. (2015). Analogy, higher-order thinking, and education. Wiley Interdisciplinary Reviews: Cognitive Science, 6(2), 177-192. https://doi.org/10.1002/wcs.1336

Saadati, F., Tarmizi, R. A., \& Ayub, A. F. M. (2015). Managing Internet-Based Tutorial Module to Support Statistics Learning Among Postgraduate Students: Learners Needs Analysis. Jurnal Pendidikan Sains dan Matematik Malaysia, 5(1), 1-17.

Saido, G. M., Siraj, S., Nordin, B., Bakar, A., \& Al Amedy, O. S. (2015). Higher Order Thinking Skills among Secondary School Students in Science Learning. Malaysian Online Journal of Educational Sciences, 3(3), 13-20.

Stockhausen, L., \& Zimitat, C. (2002). New learning: Re-apprenticing the learner. Educational Media International, 39(3-4), 331-338. https://doi.org/10.1080/0952398022000036164

Uwaezuoke, F.O., \& Ekwueme, C.O. (2015). Location, Sex, and Resource Availability Factors Affecting Technology Integration in Mathematics Learning in Abia State, Nigeria. Journal of Education Policy and Entrepreneurial Research, 2(3), 91-100.

Vurayai, S. (2020). Rurality and Exclusion in Ordinary Level Mathematics in Zimbabwe: A Document Analysis. International Journal of Learning, Teaching, and Educational Research, 19(6).

Wae, V. P. S. M., Mercuriani, I. S. \& Paidi (2017). Analysis of higher-order thinking skill (HOTS) student in class XI in Ende district reviewed from the school location. Proceedings of International Conference on Innovation in Education, Science, and Culture (ICIESC-2017). (pp. 251-254) Medan, Indonesia.

Yahya, A. A., Toukal, Z., \& Osman, A. (2012). Bloom's Taxonomy-Based Classification for Item Bank Questions Using Support Vector Machines. In Modern Advances in Intelligent Systems and Tools (pp. 135-140). Berlin, Germany: Springer.

Yee, M. H., Md Yunos, J., Othman, W., Hassan, R., Tee, T. K., \& Mohamad, M. M. (2015). The effectiveness of higher-order thinking skills for generating ideas among technical students. Recent Advances in Educational Technologies. 113-118. https://doi.org/10.30880/jtet.2019.11.03.005

Zabit, M. N. M. (2010). Problem-based learning on students' critical thinking skills in teaching business education in Malaysia: A literature review. American Journal of Business Education, 3(6), 19.

Zanzali, N. A. A., Abdullah, A. H., Ismail, N., Nordin, A., \& Surif, J. (2011). Comprehensive indicators of mathematics understanding among secondary school students. from http://www.qucosa.de/fileadmin/data/qucosa/documents/8321/Proceedings394pages-SA2011_377-380.pdf 